\title{
Strategic Engagement and Religious Peace-building A case study of religious peace work in Jerusalem
}

\section{T} his article argues for the importance of a dialogue for strategic engagement and presents an analytical approach to it with reference to three different peacebuilding strategies in terms of conflict resolution theories. As a case study example, the article presents three religious organizations engaged in peacebuilding in Jerusalem and explores the different strategies utilized by them. The article further argues that each single strategy possesses a danger of going wrong, at the same time as each single strategy is a vital component as part of a parallel process along with the others - to achieve the common goal of conflict transformation.

\section{Introduction}

This article is based on a growing concern for coherency among religious peace activists which caught my attention during my previous research on religious peacebuilding in Jerusalem in 2007-11. I had selected eight religious organizations, representing both Palestinians and Israelis and all the three Abrahamitic faiths, to study how they found encouragement in their sacred texts and faith to pursue peace in the Holy Land. At the beginning of my research I expected to find a religious peace movement consisting of Palestinians and Israelis working together for the same goal. Unfortunately, what I found instead was a fragmented number of religious organizations which rarely saw the significance of the others' work. Despite this general neglect of one another, it was obvious that each organization was engaged in some kind of peace work. By making a distinction between the different strategies as structural, cultural or elite peacebuilding, it was clear that each pursued conflict transformation.

The tendency I found in my own material is fur- ther supported by previous research on interfaith dialogue among Israelis and Palestinians. In 2007 Mohammed Abu-Nimer, Emily Welty and Amal I. Khoury voiced similar concerns:
A clear distinction emerges between using a religious approach to deepen one's faith and to understand other faiths, versus using religious beliefs as an instrument to reduce violence and preach for political coexistence. The analysis that follows shows how all three of the process models described above point to a clash - not of theologies, but of views on the relationship of religion and nationalism, or religion and political justice. (Abu-Nimer et al. 2007: 66)

According to this study these distinctions are specifically related to differences between Israeli and Palestinian participants, where Israelis generally see interfaith dialogue as a way of understanding oneself and the other, while Palestinians see interfaith dialogue as a way of combatting political injustice. ${ }^{1}$ Similar antagonisms were expressed when Arab leaders met during a gathering in New York arranged by the United Nations in November 2007. ${ }^{2}$ During this conference the President of Libya said the following:

The effectiveness of the dialogue in question remains subject to the dynamics of asymmetrical power relations ... for how could any

1 Although the Israeli organization Rabbis for Human Rights was an exception. Abu-Nimer et al. 2007: 224-6.

2 See General Assembly of the United Nations 2008. This gathering and the response from the Arab leaders are also mentioned in Wang 2009. 
dialogue flourish and progress where the Israeli occupation of the Palestinian and Arab territories persists, where the national and human rights of the Palestinian people are systematically violated? (Sleiman 2008)

Parallel statements, which demanded justice for the Palestinians and a solution to the question of Jerusalem before any dialogue could flourish, were given by King Abdullah II of Jordan (King Abdullah II of Jordan 2008), Mohammad Saed Tantawy from Egypt (Tantawy 2008) and the Prime Minister of Morocco Abbas El Fassi (El Fassi 2008).

In this way Israeli peace activists are generally excluded from interreligious dialogue in the Arab world, and this has also had a negative effect on peace work between Israelis and Palestinians.

This fear among Palestinians that cooperation and dialogue with Israelis will eventually preserve the status quo and the occupation is not new or limited to interreligious peace activism. In 1986 Edward Said gave voice to a common concern by questioning the value of dialogue in such an asymmetrical conflict as the Palestinian-Israeli conflict was (Jabri 1996: 155). Equally, a study by the Palestinian Mohammed AbuNimer (1999) shows how the dialogue programmes implemented in Israel in the gos did not lead to any social change for Arabs in Israel, but rather 'reflects what the Jewish Zionist movement wishes to transmit to Jewish youth for generations to come' (ibid. 160). In 2011 the Palestinian peace activist Aziz Abu Sarah $^{3}$ published a chronicle in which he questioned the attitude of anti-normalization because it encourages many Palestinians to deliberately reject any form of cooperation or dialogue with Israelis, for fear that such an outreach to the occupants might lead to a normalization of the occupation itself:

Anti-normalization is one of the hottest topics in the Palestinian community, although very few people can define exactly what it should mean. It is a term that gained strength in the 1980 s against accepting the status quo of the occupation. Those who supported antinormalization then were concerned about the occupation becoming a secondary issue in the Israeli-Palestinian conflict. A growing number of Palestinians working for Israeli businesses, a

3 Aziz Abu Sarah's commitment and recognition as a Palestinian peace activist can be found online: for the address of his blog see the list of websites. lack of political vision or a strategy for ending the occupation and the absence of the Palestinian case from the international discourse were alarming trends for Palestinian activists. However, since the Oslo Accords 'normalization' has become an out-moded term, a catchall argument against Israeli-Arab cooperative efforts and a cover for character assassination in Palestinian politics. (Sarah 2011)

Sarah further exemplifies how this fear of normalization has led many Palestinians away from acknowledging Israeli peace organizations who try to combat prejudices and put an end to violence. Sarah calls this kind of rejection the work of 'armchair critics who complain about the occupation without taking action' (Sarah 2011). He goes further and calls this attitude an obstacle to genuine peace work. Sarah encourages an opposition to occupation that acknowledges the outreach of Israeli peace activists:

Cooperation between Israelis and Palestinians recognizing the goal of ending the occupation is an important act. It is not IPCRI and other types of joint Palestinian-Israeli organizations that Palestinians should be fighting, as some campaigns in the West Bank have been focusing on. It is the occupation. We as Palestinians must rethink what is normal so that we can truly fight normalization, which is accepting the status quo without action. Israelis standing hand in hand with Palestinians for freedom and human rights are brothers in arms and there is nothing 'normalizing' about that except common humanity. (Sarah 2011)

Thus, this statement encourages a new approach to resistance among Palestinians that includes cooperation with Israeli peace activists.

The discussion above exemplifies the need to explore different strategies among Israeli and Palestinian religious peace organizations. Thus, the question this article asks is: how best to develop an analytical approach for strategic engagement in relation to religious peacebuilding?

\section{Dialogue for strategic engagement}

Oliver Ramsbotham, Hugh Miall and Tom Woodhouse (2011: 394) suggest replacing dialogue for mutual understanding with dialogue for strategic engagement in intractable conflicts. Ramsbotham, 


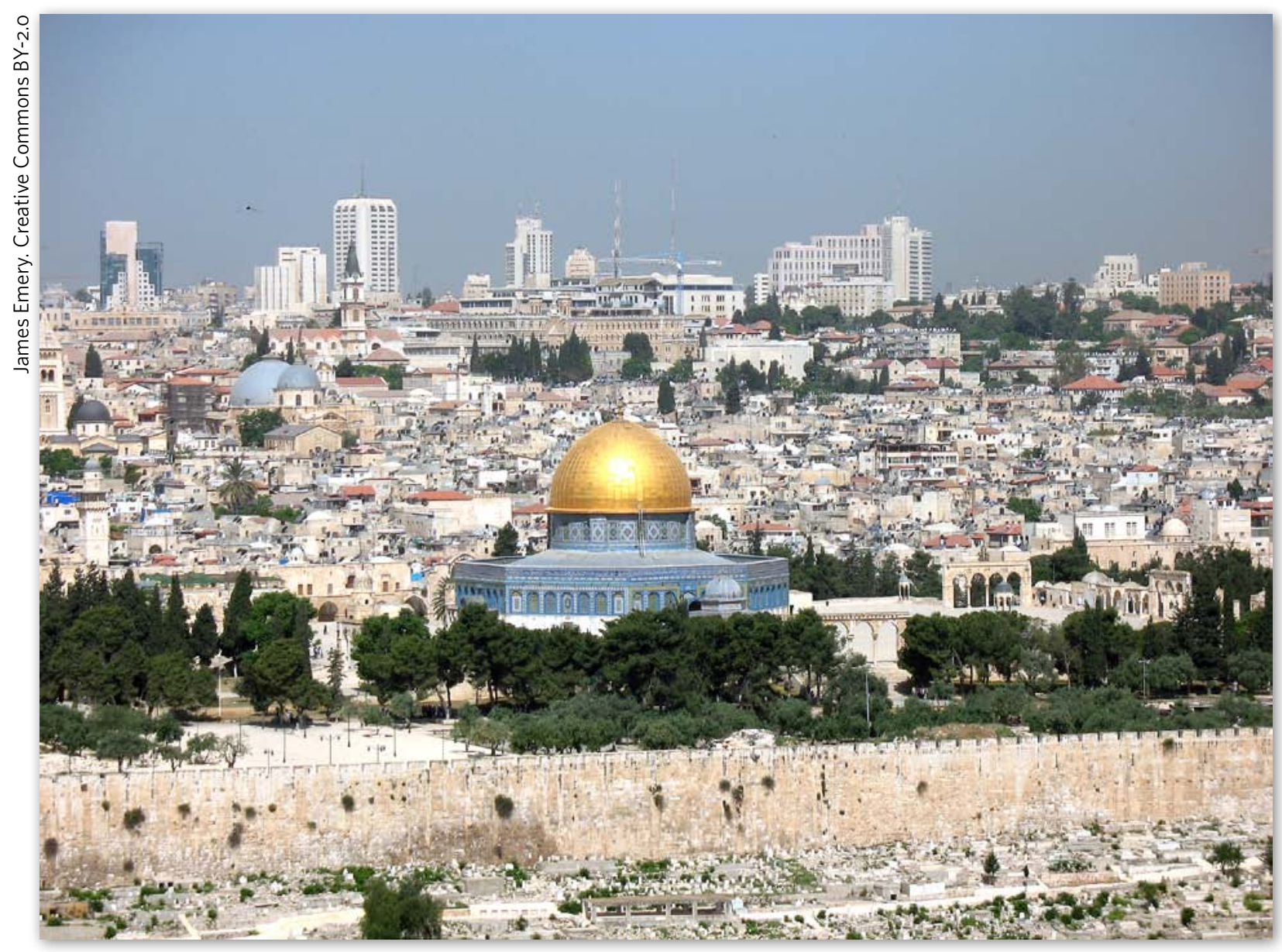

Jerusalem from Mount Olives.

Miall and Woodhouse use the Israeli-Palestinian conflict as a case study to illustrate why this new approach is needed in intractable conflicts:

... what is to be done in intractable conflicts when dialogue for mutual understanding proves to be premature and systemic approaches to conflict resolution as yet gain no transaction? What when conflict parties refuse to distinguish positions from interests and needs, resists reframing competition into shared problemsolving, will not convert adversarial debate into constructive controversy. (Ramsbotham et al. 2011: 377)

To answer these questions they suggest looking in the opposite direction - by acknowledging, exploring and understanding what lies at the heart of the radical disagreement, instead of dismissing radical disagreement in a premature search for mutual understanding. Ramsbotham, Miall and Woodhouse suggest replacing dialogue for mutual understanding with the promotion of dialogue for strategic engagement. While Ramsbotham, Miall and Woodhouse focus on general peacebuilding, my concern in this article is to understand how a focus on strategic engagement between Israeli and Palestinian religious peace activists can be helpful in understanding the relationship between the different strategies adopted by religious peace activists. The discussion put forward here is based on the assumption that genius conflict transformation is dependent on the mutual success of three different strategies: cultural peacebuilding, structural peacebuilding and elite peacebuilding. (Ramsbotham et al. 2011: 13-16) ${ }^{4}$

This article exemplifies the abovementioned range of strategies by conducting a case study of three religious organizations in Jerusalem. One is Palestinian, one Israeli and one Israeli-Palestinian.

4 Ramsbotham and others (2011) also mention other strategies which are not mentioned in the context of this article on religious peacebuilding. These strategies are peacekeeping and war limitation. 
Before I present these organizations, I will clarify the following central concepts: religious peacebuilding, structural-cultural and elite peacebuilding. Then I will make a suggestion as to how to monitor religious peace activism in a constructive way.

\section{Religious peacebuilding and peacebuilding}

Before the concept religious peacebuilding is discussed it is important to emphasize that the Israeli-Palestinian conflict is not a religious conflict, but a territorial one (see, e.g., Breger et al. 2010). Nevertheless, the territory is sacred, and holy sites play a detrimental role in the Israeli-Palestinian conflict (see, e.g., the introduction in Breger et al. 2010; also Kelman 2004).

According to David Little and Scott Appleby, religious peacebuilding is a term used to 'describe the range of activities performed by religious actors and institutions for the purpose of resolving and transforming deadly conflict, with the goal of building social relations and political institutions characterized by an ethos of tolerance and nonviolence' (Little and Appleby 2004: 5). According to Little and Appleby this process is meant to lead to a structural reform - where efforts are made to build institutions and foster civic leadership that will address the root cause of the conflict and develop long-term practices and institutions conducive to peaceful, nonviolent relations in the society. Following Little and Appleby, religious actors can serve in the post-conflict phase of the process, among others, as educators and institution builders. As educators they '... have a role to play during each of the stages of conflict transformation, whether it be to sensitize a society to inequities in the system; to foster the understanding and build the skills of advocacy, conflict resolution, democracy or living with diversity' (ibid. 10). As institution builders the religious leaders can develop strategies for opposing political and social injustice non-violently by drawing upon their religious traditions. Thus, following this definition of religious peacebuilding, it is clear that religious peacebuilders seek to change the conflict at both an institutional and social level of society.

Religious peacebuilding occurs at several levels of society, just as contemporary peacebuilding does. In this connection I would like to present Renee Garfinkel's report What Works? Evaluating Interfaith Dialogue Programs (2004). ${ }^{5}$ According to Garfinkel, interfaith dialogue programmes can be categorized according to the dimension of the participants' occupation:

Elites are people in top-level positions in politics, religion, academia, and other fields who have the potential to influence widely the group's ideas, practice and values. Mid-level people whose occupations are thought to have an influence over smaller groups of people, in a more personal way. Mid-level programs might be aimed at teachers, for example, or local clergy. Grassroots participants or activists are individual citizens. Their experience is more intimate, having an impact on their families, friends, customers, and others with whom they have personal relationships. (Garfinkel 2004: 3, italics in original)

According to Renee Garfinkel, each of these three levels has a different impact on the people in a conflict area. While high-level religious leaders can speak for their whole communities and have a longterm impact, the lower levels can have a more direct impact, although it will be basically limited to individual change.

Contemporary conflict resolution also distinguishes between cultural peacebuilding, structural peacebuilding and elite peacebuilding (Ramsbotham et al. 2011: 14-16). Conflicts can be perceived as a dynamic process in which 'structure, attitudes, and behaviour are constantly changing and influencing one another' (ibid. 11). Cultural peacebuilding is interested in the social relationships within a given society. Structural peacebuilding is interested in changing the structures - or institutions - in a conflict area which legitimate the conflict. Elite peacebuilding is mainly conducted by the decision-makers or political authorities. Taking into account this division of peacebuilding, the main goal is nevertheless the same: conflict transformation. Ramsbotham, Miall and Woodhouse define conflict transformation as the fundamental level of peacebuilding: '... it implies a deep transformation in the institutions and discourse that reproduce violence, as well as in the conflict parties themselves and their relationship. It corresponds to the underlying tasks of structural and cultural peacebuilding' (ibid. 31-2).

peacebuilding is also common within contemporary conflict resolution theory. See Ramsbotham et al.

2011: 27 
Following the discussion so far, it might be possible to suggest that religious peacebuilding can be conducted by means of a variety of strategies. As educators, religious actors can promote mutual understanding and develop the skills of living with diversity, and as such engage themselves in cultural peacebuilding. As institution builders they can oppose political and social injustices in the system, and as such engage themselves in structural peacebuilding. In addition Garfinkel points out the significant impact that top-level religious leaders can have within interfaith programmes, by widening the influence of the group's ideas, practices and values, and as such they have an impact on elite peacebuilding.

In the next section of this article I will exemplify how these three strategies are pursued by three different religious organizations in Jerusalem.

\section{Case-study example}

The empirical material presented below was gathered during my PhD work, carried out in 2007-11, and is based on interviews and documents from the organizations (Wang 2012: 80-3). In this article I present a selection of the material from three of the eight organizations I studied during the course of my $\mathrm{PhD}$ research work as a case study example of the different strategies taken by religious peace activists in Jerusalem. The first organization I would like to present is Sabeel, which is a Palestinian Christian organization established in 1990 as a response to the first Palestinian Intifada, but also as a result of Israeli policies after 1967. Sabeel has developed a Palestinian liberation theology which seeks to empower the Palestinian Christian minorities and implement nonviolent resistance to the occupation. The liberation theology of Sabeel is based on an understanding of Jesus as having himself lived under occupation; thus Sabeel affirms its commitment to make the gospel relevant ecumenically and spiritually in the lives of the local indigenous Church congregation:

Our faith teaches that following in the footsteps of Christ means standing for the oppressed, working for justice, and seeking peace-building opportunities, and it challenges us to empower local Christians. Since a strong civil society and a healthy community are the best supports for a vulnerable population, Sabeel strives to empower the Palestinian community as a whole and to develop the internal strengths needed for participation in building a better world for all. (Sabeel website)

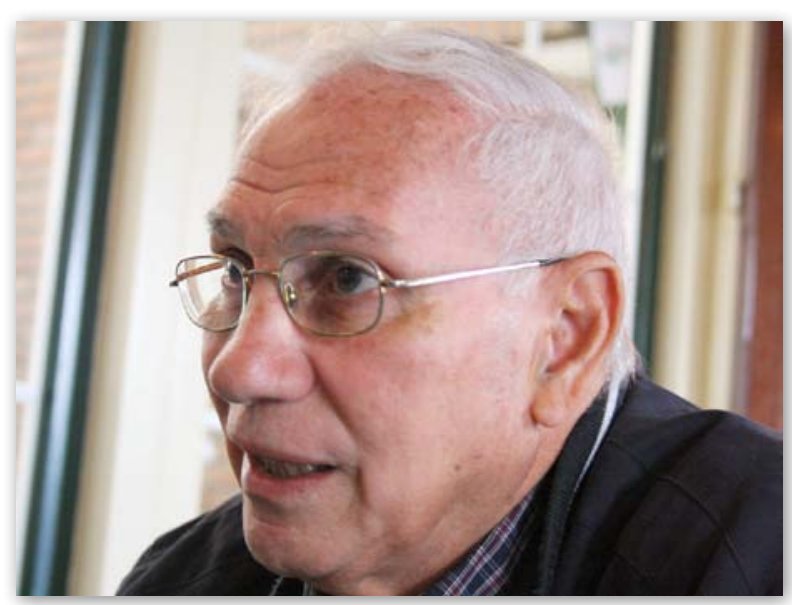

Naim Ateek, director of Sabeel.

As mentioned, the main concern of Sabeel is to develop a liberation theology for the Palestinian Christians. This is explained by the founder of Sabeel, Naim Ateek, as follows:

The message of Jesus acquires renewed relevance. His message of justice and liberation helps us focus on the inequalities and discrimination that are apparent within the society. At the same time we need to consider the obstacles that stand in the way of achieving a just peace in the political realm. (Ateek 2009) ${ }^{6}$

According to Naim Ateek, the need to develop a new liberation theology for the Palestinian people arose as a result of the pain they experienced after occupation and with the emergence of western Christian Zionist supporters of the settlers. Thus, it also seeks to develop an inclusive land theology in some way as a counter-theology to religious Zionism - both Christian and Jewish. Sabeel represents a minority group in relation to both Palestinians and Israelis. It seeks dialogue and cooperation with Palestinian Muslims in order to empower the Palestinian Christian community. On the other hand, it is opposed to dialogue with the Israelis, and believes dialogue only can start after an end to occupation. The director of Sabeel, Naim Ateek argues that a divine paradigm for reconciliation is impossible in the present conflict and therefore suggests a human paradigm, effected by means of six steps. In Ateek's final chapter 'From

6 Similar statements on how a Palestinian liberation theology must focus on the life of Jesus in the Gospel are made in Ateek 2003: 2. 


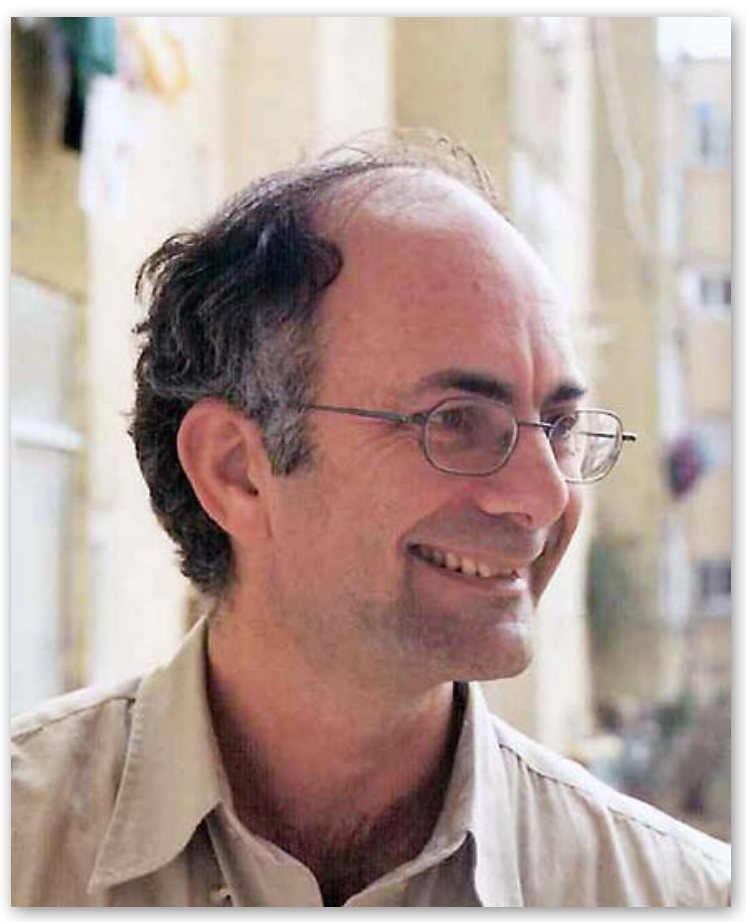

Yehuda Stolov, director of IEA.

justice to forgiveness' he presents these six steps, which need to be taken before a final reconciliation and forgiveness process can take place. They can briefly be listed as follows:

1. Confront and analyse the roots of the conflict to listen to and understand the two narratives of the conflicting parties.

2. Israeli occupation must end and Palestinian violence stop. And it is also important to understand the Palestinian violence as a response to Zionism.

3. Justice must be done in accordance with international law and Israel must be willing to make amends and offer restitution. ${ }^{7}$

4. The real work begins when justice has been established, to end all violence on both sides.

5. Healing can begin by means of a long process. A Truth and Reconciliation Commission should be established to review the history of the conflict.

6. Forgiveness is the final step in the process of healing. (Ateek 2008: 185-6)

7 The importance of justice is strongly emphasized in Ateek's first book as a prerequisite for peace; Ateek 1989: 177 .
According to this process Israeli occupation must end before healing and dialogue can begin. ${ }^{8}$

The second organization dealt with here is the Israeli Interfaith Encounter Association (IEA) founded in 2001 by the Orthodox Jew Yehuda Stolov as an interreligious organization in Israel engaged in religious dialogue through face-to-face encounters. The encounters are held in private homes on both sides of the border, and address religious issues such as holy sites, high holidays, religious ethics and values. It seeks to be a human component of peace, and to challenge the exclusivity of political discourses and obstacles by ignoring them completely, thereby showing how individuals can be friends even among the most extreme groups. It has managed to assemble an encounter group including Palestinians from $\mathrm{Abu}$ Dis and Jewish settlers from Maale Adumim. The approach and strategy of the IEA is formulated by the director as follows:

This is why I believe that any political agreement won't be sustainable without plowing both societies to overcome these negative stances: We need to turn to mutual understanding, respect, friendship and mutual trust - without these it is impossible really to maintain life together over an extended period of time ... when we have achieved these things, I think it will be possible to accomplish political agreements fairly easily and that they will be sustainable. ('Interview with Yehuda Stolov' 2009)

Stolov further argues that the ongoing political conflict between Israelis and Palestinians has developed more towards a psychological conflict than one of rational disagreement. Stolov believes religion has the potential to change relationships:

The problem that we are facing in the Holy Land today is not a mathematical problem, on how to divide the land, it's a psychological problem. It's not part of the rational reality, it is part of the, what you say, the human reality. And I think this is where many peace organizations have gotten it wrong. And of course, many of the peace organizations are very secular oriented, and because of that they fail to see the

8 Sabeel is presented in my thesis How Can Religions Contribute to Peace in the Holy Land (Wang 2012: 114-27). 
potential of religion. (Interview with Stolov in Wang 2012: 162)

During the encounters between Jews, Muslims and Christians every dimension of religion is explored in a personal setting. Religious issues such as sacred narratives and figures, reconciliation and forgiveness in the sacred texts or holidays in the three traditions are explored. The IEA also conducts a programme called 'Cross-Cultural Study Visits' where they visit sacred sites together to understand the significance of holy places for the religious other. The IEA works to form several encounter groups among Jews, Muslims and Christians living in both Israel and the Palestinian territories. The aims of the groups are to develop good relationships between Jews, Muslims and Christians in each community, and thus form a mini-community, characterized by mutual understanding and respect. The idea is that the work done in the Israeli state will form an inner circle, while the dialogue between Palestinians and Israelis is the next circle, and further a dialogue between Israel and the Middle East another circle (Interfaith Encounter Association 2009):

Unlike most other dialogue organizations, we work with, rather than around, the deep cultural roots, beliefs, and traditions of the peoples of the Middle East. Each encounter is centred on a religious theme and features a carefully planned program of joint study and dialogue. The group then coalesces into a single community that respects the unique identity of each of its 'sub communities' and participants, which helps create a long-term process of grassroots peace building. By constructively engaging with core religious and cultural values, while explicitly discouraging partisan bickering that might close off constructive dialogue, our approach successfully involves social and political groups that may feel very uncomfortable with other approaches. (Interfaith Encounter Association 2008)

In this way the IEA is engaged in a long-term project to transform the societies and relationships among members from the three monotheistic faiths living in Israel, Palestine or the Middle East (Wang 2012: 158-69).

The third organization is not really an organization, but rather an Israeli-Palestinian consultative body representing the highest official religious authorities in the Holy Land, encompassing two peoples and three religions (Wang 2012: 13). The member institutions of the Council of Religious Institutions of the Holy Land (CRIHL) are the Chief Rabbinate of Israel, The Heads of the Local Churches of the Holy Land, The Ministry of Islamic Waqf at the Palestinian Authority, and the Islamic Sharia Court of the Palestinian Authority. The CRIHL presents its main task as follows:

As religious leaders of different faiths, who share the conviction in the one Creator, Lord of the Universe; we believe that the essence of religion is to worship God and respect the life and dignity of all human beings, regardless of religion, nationality and gender.

We accordingly commit ourselves to use our positions and good offices, to advance these sacred values, to prevent religion from being used as a source of conflict, and to promote mutual respect, a just and comprehensive peace and reconciliation between people of all faiths in the Holy Land and worldwide. (CRIHL 2010)

This statement is further elaborated through five goals listed by CRIHL:

1. To be an open channel of communication between the Israeli and Palestinian institutional religious leadership;

2. to ensure a working relationship with the Government of Israel and the Palestinian Authority; ${ }^{9}$

3. to promote mutual acceptance and respect among the religious communities through dialogue, education and the media;

4. to promote respect for the holy sites of each religious community; and

5. to engage religious leaders internationally. ${ }^{10}$

In 2007 CRIHL produced a document which clarifies some guiding principles behind the communication between the member institutions. The document lists four aims:

9 This means the Palestinian authorities in the West Bank, not Gaza.

10 The text of this list has been shortened by me. For the whole text see CRIHL 2010. 
1. Ensuring that my statements emphasize the value of our collective effort and the fact that we are working to improve the atmosphere of dialogue between one another.

2. Avoid any public statement that could endanger our ability to work together.

3. Discuss the details of those matters upon which we most deeply disagree in our private meetings and not in public.

4. Emphasize the importance of our dialog and the good will between us despite our differences. (CRIHL 2007a)

In this way disagreements are not meant to reach the public sphere; only joint statements do so (CRIHL $2007 \mathrm{~b}$ ). The document further acknowledges the different needs of Israelis and Palestinians by saying: 'Palestinians yearn for the end to occupation and for what they see as their inalienable rights. Israelis long for the day when they can live in personal and national security. Together we must find ways of reaching these goals' (ibid.). The CRIHL's mission is to be a religious partner in the political peace process by giving advice on issues related to religion.

The CRIHL is currently conducting three public projects. The first project is called 'Universal Code of Conduct on Holy Sites Pilot'. The purpose of the project is 'safeguarding all Holy Sites in the region from being abused for political and hateful purposes' (see CRIHL 2011). The second project is the 'Israeli-Palestinian Schoolbook Project' launched in August 2009, and which for the first time creates a joint Israeli-Palestinian research team to study the 'portrayal of the other' in Palestinian and Israeli schoolbooks. The programme is also followed up by a scientific advisory panel, consisting of European, American, Israeli and Palestinian experts. The study focuses upon all aspects of the other, such as its historical, religious, personal and political dimensions (CRIHL 2009). The study was published on 4 February 2013 (Zeveloff 2011). The third project is to empower young religious leaders to engage in fruitful dialogue and cooperation among Israelis and Palestinians from the three Abrahamitic faiths (CRIHL 2013).

\section{Analysis}

In the following analysis I will first try to situate the respective strategy of each of the three religious organizations as it orients towards peacebuilding. Next I will discuss how each of these different strategies on the one hand counteracts the other strat-

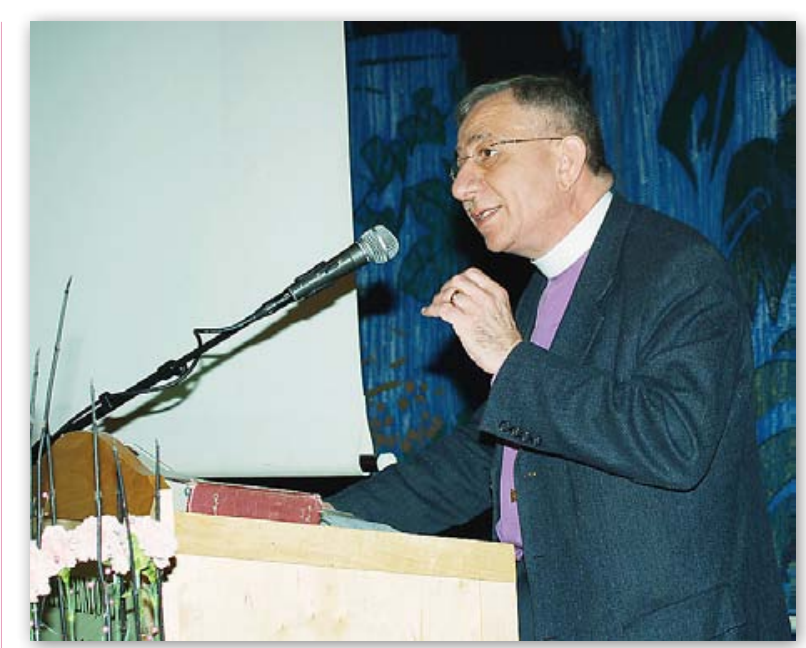

Bishop Munib Younan, representing The Heads of the Local Churches of the Holy Land in CRIHL, Jerusalem.

egies, while on the other hand is mutually dependent on the others to achieve conflict transformation. Finally, I present an analytical approach to a dialogue for strategic engagement.

Following the definition of religious peacebuilding as developed by Little and Appelby, Sabeel is engaged in religious peacebuilding as it seeks to build 'political institutions characterized by an ethos of tolerance and nonviolence' (Little and Appelby 2004: 5). The process of its work is meant to lead to a structural reform which will end the occupation by means of nonviolent resistance and by sensitizing 'society to inequities in the system', as described by Little and Appelby (ibid.). Sabeel works at what Garfinkel calls 'the mid-level' with religious leaders, but also at the grassroots level by engaging youth groups and members of the churches (see below). Following the distinction between three different kinds of peacebuilding, Sabeel is engaged in structural peacebuilding through nonviolent resistance against occupation. As religious peacebuilders Sabeel find strength and encouragement in the Christian faith and sacred texts to resist and challenge inequalities and work for an end to Israeli occupation. Sabeel works among people at both the grassroots and midlevels of society.

Secondly, I would like to address the same question in relation to the Israeli organization the Interfaith Encounter Association. The IEA is engaged in religious peacebuilding, with the goal of building social relations' (see Little and Appelby 2004: 5) which it is believed will eventually put an end to the conflict. By emphasizing the religious dimension of forgiveness and reconciliation among the three 
Abrahamitic faiths, without ignoring differences in these three traditions, the IEA also draws 'upon their religious tradition' (ibid. 10). Following Garfinkel, the IEA works at the grassroots level by engaging common people from all kinds of professions. In relation to contemporary conflict resolution theory, the IEA enacts cultural peacebuilding, and has - as we have seen - been able to arrange meetings between Palestinians from Abu Dis and Jewish settlers, perhaps mainly because it does not discuss politics. By exploring common religious issues the IEA has managed to break down prejudices and stereotypes between the two peoples and three faiths and thus pursue a culture of peace and coherence. The IEA works mainly among people at the grassroots level of society.

The third organization I would like to address is the Council of Religious Institutions of the Holy Land. As we have seen this council represents the highest religious authorities among Jews, Muslims and Christians in Israel and on the West Bank. The CRIHL works at what Garfinkel would call the elitelevel of religious peacebuilding (Garfinkel 2004: 3) as they function as a council for the political authorities in relation to questions affecting the religious communities. Its statement also clearly situates the Council within religious peacebuilding, as it is 'drawing upon their religious tradition' to promote good and sustainable relations (Little and Appelby 2004: 10). It can be argued that the CRIHL works at the elite level of peacebuilding through its consultation with political leaders regarding specifically holy sites. From the presentation above we have seen how it seeks to take both the Palestinians' need for an end to occupation and the Israelis' concern for security into consideration and as such supports both structural and cultural peacebuilding. In this way it acknowledges the fear behind the so-called 'stigma of normalization' (Sarah 2011) and also the need to enter into dialogue to promote trust and confidence among the two peoples. In this way, the three organizations presented here exemplify how religious peacebuilding can promote structural, cultural and elite peacebuilding.

On the other hand, each of the strategies adopted by the religious organizations runs the risk of counteracting the others at some point. First of all, Sabeel rejects any dialogue with Israelis until a political agreement is reached and amends and restitution are made in accordance with international law. By resisting dialogue Sabeel counteracts cultural peacebuilding which is vital to end misconceptions and prejudices with regard to the others. It can be argued further that purely structural peacebuilding, that raises a critical voice against the occupiers might also reproduce the conflict. By clearly resisting cooperation and dialogue with the other, Sabeel might situate itself among those whom Aziz Abu Sarah argues are trapped in 'the stigma of normalization', who do not distinguish between dialogue among Israeli and Palestinian peace organizations, and dialogue with general Israeli institutions. This means that although Sabeel is engaged in a positive process with the work of nonviolent resistance through structural peacebuilding, it might be counterproductive in reproducing stereotypes and misconceptions of the other.

To return to the second organization presented here, it may be said that the Interfaith Encounter Association (IEA) is engaged in cultural peacebuilding, but by ignoring political disagreements which might be critical to the structure between the parties in conflict, it ignores the importance of engaging in structural peacebuilding. In this way the IEA runs the risk of making the error of ignoring a key fear among Palestinians, which, as we have seen, is that dialogue will only normalize the occupation. Nevertheless, the decision to adopt this strategy is taken consciously to break the ongoing negative discussion in politics by showing how friendship can develop when political disagreement is left behind. The IEA believes that only when such friendship has developed can the two peoples be able to find good and sustainable solutions (Interview with Yehuda Stolov 2009). Nevertheless, it is clear that the different strategies taken by Sabeel and the IEA work in different directions. While Sabeel believes that nonviolent resistance will lead to a political agreement and open the way for dialogue and reconciliation, the IEA believes that interreligious dialogue will lead to good relations which eventually will make it easy to find a sustainable political agreement.

The Council of Religious Institutions of the Holy Land (CRIHL) seems to acknowledge the different needs among Israelis and Palestinians, and thus the different strategies taken. When the CRIHL states that for the Palestinians an end to the occupation is a necessity, it is possible to argue that structural peacebuilding is the best way of achieving that goal. While at the same time the CRIHL states that Israelis need security, it is further possible to argue that cultural peacebuilding is the best strategy for achieving that goal. Thus, the CRIHL seems to manage to understand and promote these different needs and strategies. On the other hand, as a council for the top tier of religious leadership, the Council does not make 
any public announcement unless the members of the Council have managed to reach an agreement. Thus, the CRIHL runs the risk of falling into the error of not offering public statements when a crisis occurs, and in this way not assisting the grassroots or midlevels of religious peacebuilding in a constructive way at such difficult times. Thus, the discussion so far makes it possible to argue that each of the strategies is potentially mutually counterproductive if left on its own. This means that while structural, cultural and elite peacebuilding are all needed to achieve conflict transformation, each alone possesses the danger of being counterproductive.

The analysis shows how each of the organizations presented here run the risk of going wrong if they are conducted in isolation from the others - which leads us to the concept of conflict transformation. Conflict transformation is, as mentioned, the fundamental task of structural and cultural peacebuilding (Ramsbotham et al. 2011: 31-2). On the other hand, this article argues that Ramsbotham, Miall and Woodhouse's suggestion of replacing dialogue for mutual understanding with the promotion of dialogue for strategic engagement should be further developed. Instead of replacing dialogue for mutual understanding it should focus on strategic engagement and make a clear distinction between cultural, structural and elite strategies for peacebuilding, viewing each strategy as a process which is dependent upon the others. The focus on strategic engagement can function as an analytical approach which is able to reconsider the relationship between these three different strategies and how together they can promote conflict transformation. Thus, the argument in this article is that a focus on strategic engagement is vital for an understanding and effective analysis of how different peace-organizations relate to one another. In other words, the approach of these three different organizations can be divided into three different strategies, each of which emphasize a unique approach towards religious peacebuilding, at the same time as each is dependent on the others.

The first strategy is cultural peacebuilding. As a strategy within religious peacebuilding it can promote interreligious dialogue among the parties in conflict and as such breaks down stereotypes and prejudice in relation to 'the other' - not just the religious other, but also the other in the conflict. On the other hand, cultural peacebuilding on its own runs the risk of being counterproductive if it ignores the structural injustices inherent in the conflict. Cultural peacebuilding is also dependent on elite peacebuild- ing, which can produce a final political agreement and further advance cultural peacebuilding.

The second strategy is structural peacebuilding. As a strategy within religious peacebuilding it can draw on its religious traditions and calling in order to put an end to injustice and empower the weaker social elements in the conflict. On the other hand, it also runs the risk of going wrong if it ignores hostility and prejudices among the parties and thus unconsciously reproduces the conflict by its criticism. Just as with cultural peacebuilding, structural peacebuilding is dependent on the other two strategies to promote conflict transformation.

The third strategy is elite peacebuilding. As a strategy within religious peacebuilding religious leaders can play a vital role as a consultative body for politicians on religious matters. Religious leaders also have a prominent and influential voice, which makes their collective impact greater. Nevertheless, to gain a sustainable peace this approach is also dependent on cultural and structural peacebuilding strategies, as these two strategies can reach the midand grassroots levels in a more direct and profound ways. Thus, religious peacebuilding can be conducted through these different strategies, but each strategy is mutually dependent on the other.

The effectiveness of conflict transformation is dependent on the strength of how these three strategies correspond to and acknowledge each other's agendas. On the other hand if only one or two of these strategies are missing the whole peace process might be in danger of collapsing at some point. Thus, a focus on a dialogue of strategic engagement can be a useful method and an analytical approach to situate the respective organization's strategy, its limitations and its unique role in the complex process towards conflict transformation. By emphasizing each strategy in relation to both the positive potential of the strategy and the risk of going wrong, a greater awareness of these dangers might be clarified in the analysis of religious peace work.

\section{Conclusion}

The title of this article is 'Strategic engagement and religious peacebuilding' and the key word for constructing a fruitful relationship between different religious organizations engaged in peacebuilding is strategy. This article relies upon the assumption that conflict transformation can mainly be achieved and sustained when cultural, structural and elite peacebuilding strategies cooperate and fulfill each other's 
agendas. Religious peacebuilding is a vital dimension of peacework in the way it can sustain all these three strategies within peacework, and also include the religious dimension needed in any conflicts which involve the religious communities.

I would like to quote excerpt from Vivienne Jabri back in 1996 which I find relevant in this context:

One means by which conflict resolution may be defined ... is to state that this is a condition where it is recognized that each interpretation of a text, be that a poem, a novel, a painting, an interpretation of history, a myth, must be dependent on the individual drawing upon the depths of experience, which differ from individual to individual and across time and context. Conflict resolution is thus recognition of the multiple and shifting identities of individuals all of which constitute the basis of communication action. (Jabri 1996: 119-20)

Jabri thus refers to conflict resolution as a condition which must recognize multiple and shifting identities - and here I would add multiple and shifting strategies. A dialogue for strategic engagement should include openness towards how different strategies might be suitable for certain groups, while others will be more comfortable with a different strategy. The road towards peace might be different for Jewish settlers from that of Palestinian members of Hamas, and a different strategy might be needed for Palestinian and Israeli academics working at the same University. In addition, as the CRIHL states, Palestinians need an end to occupation, which requires structural changes, while Israelis need national security, which requires the trust and confidence which dialogue can offer. Still, the three dimensions of peacebuilding that peace work consists of structural, cultural and elite peacebuilding must not be ignored, nor the fact that if one of these approaches is missing it might be counterproductive. Thus, a dialogue of strategic engagement might be a fruitful analytical approach because it can evaluate diversity and cultural, structural and elite peacebuilding as mutually inclusive strategies to pursue the common goal of conflict transformation.
Yvonne Margaretha Wang is an Associate Professor at Volda University College, at the Faculty of Humanities and Education. Her interests are focused on religions in the Middle East and interfaith dialogue within the scope of conflict resolution theory. She has published her thesis on religious peacebuilding in Jerusalem. Email: wangym(at)hivolda.no

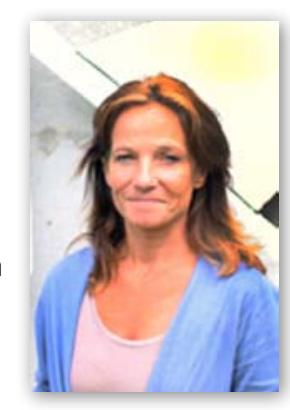

\section{List of references}

Websites in this research

Council of Religious Institutions of the Holy Land (CRIHL), official website, <http://crihl.org/>

Interfaith Encounter Association, official website, $<$ http:// interfaithencounter.wordpress.com/>

Sabeel: Ecumentical Liberation Theology Centre, official website, <http://www.sabeel.org/ourstory.php > (accessed 14.2.2011)

Sarah, Aziz Abu. A Blog for Peace in Israel-Palestine, $<$ http://azizabusarah.wordpress.com/about/> (accessed 23.4.2014)

\section{Bibliography}

Abu-Nimer, Muhammed, 1999. Dialogue, Conflict Resolution, and Change: Arab-Jewish Encounters in Israel (New York, State University of New York Press)

Abu-Nimer, Mohammed, Emily Welty, and Amal I. Khoury, 2007. Unity in Diversity: Interfaith Dialogue in the Middle East (Washington, DC, United States Institute for Peace)

Ateek, Naim Stifan, 2003. 'There is another way: the way of nonviolence, the way of fidelity', Cornerstone 28, p. 2.

-2008. A Palestinian Christian Cry for Reconciliation (Maryknoll, New York, Orbis Books)

-2009. 'Some are more equal', Cornerstone 54, p. 2

Breger, Marshall J., Yitzhak Reiter, and Leonard Hammer, 2010. Holy Places in the Israeli-Palestinian Conflict (London and New York, Routledge)

CRIHL 2007a. 'CRIHL Pledge 2007', Council of Religious Institutions of the Holy Land website, <http://www. crihl.org/content/crihl-pledge $>$ (accessed 19.11.2010)

-2007b. 'Washington Communiqué, Council of Religious Institutions of the Holy Land website, <http://www. crihl.org/content/washington-communiqu\% $\mathrm{C}_{3} \% \mathrm{~A}_{9}>$ (accessed 19.11.2010)

-2009. 'Israeli-Palestinian Schoolbook Project', Council of Religious Institutions of the Holy Land website, $<$ http://www.crihl.org/content/israeli-palestinianschoolbook-project> (accessed 1.9.2013)

-2010. 'CRIHL Mission \& Goals', Council of Religious Institutions of the Holy Land website, <http://www. crihl.org/content/crihl-mission-goals $>$ (accessed 12.12.2010)

-2011. 'Universal Code of Conduct on Holy Sites Pilot', Council of Religious Institutions of the Holy Land website, <http://www.crihl.org/content/universalcode-conduct-holy-sites-pilot $>$ (accessed 23.3.2014) 
-2013. 'Young Religious Leaders', Council of Religious Institutions of the Holy Land website, <http://www. crihl.org/content/young-religious-leaders $>$ (accessed 23.3.2014)

El Fassi, Abbas, 2008. 'Address by H.E. Mr. Abbas El Fassi, Prime Minister of the Kingdom of Morocco, High Level Meeting on Interfaith Dialogue at the General Assembly of the United Nations, 12 November 2008, United Nations website, <http://www.un.org/ga/63/ meetings/pdf/moroccoE12.pdf $>$ (accessed 8.12.2008)

Garfinkel, Renee, 2004. What Works? Evaluating Interfaith Dialogue Programs, Special Report, No. 123, United States Institute for Peace (Washington, DC, United States Institute for Peace Press), <http://www.usip. org/publications/what-works-evaluating-interfaithdialogue-programs $>$ (accessed 22.9.2014)

General Assembly of the United Nations, 2008. 'Programme of the high-level meeting on the culture of peace, 12-13 November 2008, General Assembly of the United Nations', United Nations website, <http:// www.un.org/ga/63/meetings/peace_culture_hl.shtml> (accessed 12.12.2008)

Interfaith Encounter Association 2008. 'Interfaith Encounter Association, Annual Report 2008', IEA's website, <http://www.interfaith-encounter. org/2008\%2oAnnual\%2oReport/2008Report.pdf> (accessed 7.12.2009)

-2009. 'Philosophy and method', IEA's website, <http:// interfaith-encounter.org/activities.htm $>$ (accessed 7.12.2009)

'Interview with Yehuda Stolov', Just Vision website, <http://www.justvision.org/en/profile/yehuda_stolov> (access 2.12.2009); also published at IEA's website, <http://www.interfaith-encounter.org/whoswho.htm> (access 2.12.2009)

Jabri, Vivienne, 1996. Discourses on Violence: Conflict Analysis Reconsidered (Manchester University Press)

Kelman, Herbert C., 2004. 'National identity and the role of the "other" in existential conflicts' in Islam, Judaism and the Political Role of Religions in the Middle East, ed. John Bunzl (Gainesville, University Press of Florida), pp. 61-73

King Abdullah II of Jordan, 2008. 'The Hashemite Kingdom of Jordan, remarks by His Majesty King Abdullah II at the High Level Meeting of the United Nations General Assembly on interfaith dialogue, New York, 12 November 2008, United Nations' website <http:// un.org/ga/63/meetings/pdf/jordanE12.pdf $>$ (accessed 8.12.2008)

Little, David, and Scott Appleby, 2004. 'A moment of opportunity? The promise of religious peacebuilding in an era of religious and ethnic conflict' in Religion and Peacebuilding, ed. H. Coward, and S. Smith (Albany, State University of New York Press), pp. 1-26 Ramsbotham, Oliver, Hugh Miall, and Tom Woodhouse, 2011. Contemporary Conflict Resolution: The Prevention, Management and Transformation of Deadly Conflicts (Cambridge, Polity Press)
Sarah, Aziz Abu, 2011. 'What is normal about normalization', Aziz Abu Sarah's website, <http://972mag.com/ what-is-normal-about-normalization/31262/> (accessed 19.3.2014)

Sleiman, Michel, 2008. 'Address by H.E. General Michel Sleiman, President of the Republic of Lebanon at the High-level Meeting of the General Assembly on the Dialogue between Cultures and Religions, New York, November 12, 2008', General Assembly of the United Nations, United Nations website, <http://www.un.org/ ga/63/meetings/pdf/lebanonE12.pdf $>$ (accessed 12.12.2008)

Tantawy, Mohammad Saed, 2008. 'Statement by His Eminence Dr. Mohammad Saed Tantawy, The Grand Imam of Al-Azhar before the General Assembly on Item 45: "Culture of Peace", New York, 12 November 2008', United Nations website <http://www.un.org/ ga/63/meetings/pdf/egyptE12.pdf $>$ (accessed 8.12.2008)

Wang, Yvonne Margaretha, 2009. 'Religionsdialog og fredsarbeid i et hellig land', Nordisk tidsskrift for Midtøsten studier, Babylon 1, pp. 34-43

-2012. How Can Religion Contribute to Peace in the Holy Land? A Study of Religious Peacework in Jerusalem, doctoral thesis, University of Oslo, <https://www.duo. uio.no/handle/10852/37783>

Zeveloff, Naomi, 2011. 'U.S. Funding Rigorous Study of Palestinian and Israeli Textbook Incitement', The Jewish Daily Forward, 27.6.2011, <http://forward.com/ articles/139177/> (accessed 27.6.2011) 